\title{
GERMINATION AND VIGOR OF INDUSTRIALLY TREATED MAIZE SEEDS
}

\author{
GERMINAÇÃO E VIGOR DE SEMENTES DE MILHO TRATADAS INDUSTRIALMENTE
}

\author{
Raianny dos Reis Teixeira ${ }^{1}$, Joseanny Cardoso da Silva Pereira ${ }^{2}$ \\ ${ }^{1}$ Faculdade Evangélica de Goianésia, Departamento de Agronomia, Goianésia,Goiás, Brasil.raianny.teixeira_15@hotmail.com \\ 2 Faculdade Evangélica de Goianésia, Goianésia, Goiás, Brasil. josycard@yahoo.com.br
}

\section{Info}

Recebido: 03/2019

Publicado: 06/2019

ISSN: 2595-6906

\begin{tabular}{l}
\hline Palavras-Chave \\
Zea mays L; Tratamento químico; \\
Qualidade fisiológica. \\
Keywords: \\
Zea mays L; Chemical treatment; \\
Physiological quality.
\end{tabular}

\section{Resumo}

0 tratamento industrial de sementes combina a aplicação de inseticidas, fungicidas, nematicidas, micronutrientes e outros produtos. No entanto, a submissão das sementes a combinação de diversos produtos pode causar fitotoxidade, resultando na redução da viabilidade e do vigor, a qual é diretamente proporcional ao aumento do período de armazenamento do material. Assim, objetivou-se determinar o vigor de sementes de milho e a porcentagem de germinação em substratos quando submetidas a dois tipos de tratamento industrial em função do tempo de armazenamento. 0 delineamento experimental foi o inteiramente casualizado, em esquema fatorial $2 \times 2 \times 2$ (dois tratamentos, dois tempos e dois substratos/dois testes de vigor/dois teste de emergência) para os testes de germinação, vigor e emergência. As sementes de milho híbrido foram tratadas com dois tipos de tratamentos industriais: TSI3 (combinação de três produtos - K-Obiol $25 \mathrm{CE}$, Actellic $500 \mathrm{CE}$, Maxim Advanced) e TSI4 (combinação de quatro produtos - KObiol 25 CE, Actellic 500 CE, Maxim Advanced, Cruiser 350 FS). As variáveis analisadas foram: germinação, vigor e emergência. No teste de germinação, verificou-se que, quando acrescentada a vermiculita, houve maior percentual de germinação em sementes de milho. Quando acrescentado o thiametoxan, a co mbinação de produtos no tratamento das sementes de milho provocou efeito prejudicial à sua qualidade fisiológica proporcionando redução na germinação e no vigor. As sementes de milho tratadas industrialmente apresentaram redução no vigor quando submetidas ao teste de envelhecimento acelerado após o prolongamento do período de armazenamento. 


\section{INTRODUCTION}

Maize (Zea mays L.) is among the world's most important crops, with great availability of varieties with common agronomic characteristics (GOULART, 1993), whose seeds are multiplied by farmers for consecutive years (AGUILERA et al., 2000). It is widely used in human nutrition and feed formulation (OLIVEIRA, 2009) and is also the most widespread crop in the national territory, due to the wide adaptability and its usefulness. In Brazil, especially in commercial crops, the use of hybrid corn seeds is predominant and the cost of using them is compensated by the higher productivity at harvest (FUCK; BONACELLI, 2007).

The use of technologies aimed at increasing productivity guarantees high quality inputs, as in the case of seeds, which makes it possible to pay the yields and increase them according to the demand (AGUILERA et al., 2000). According to Popinigs (1985), the physiological quality of seeds is the sum of all the genetic, physical, physiological and health factors that compromise their productive capacity, characterized by germination, vigor and longevity. This same author affirms that the use of seeds with high quality reflects directly in the result of the harvest, because it generates population with greater uniformity and more vigorous plants, reduces the possibility of disease transmission through seeds and thus allows greater productivity, The production per plant per area has greater guarantee.

During the maturation, storage and postsowing period, seeds are exposed to insect and pathogen attack, which favors grain deterioration, causing losses in the physiological and sanitary quality of seeds (HENNING et al., 2011). Germination and vigor reduction (GOULART, 1997). To prevent and control these organisms, seed treatment is the first step, and commercialized seeds are usually treated during processing (DHINGRA, 1985).

Seed treatment is a method that provides seed or seedling protection against most soil pests either by the direct effect of the pest contact with the product, thus causing its death, or by the effect of repellency, preventing the pest cause damage to culture at the critical stage (EMBRAPA, 2007); and against storage pests, responsible for the physical deterioration of the batch of stored seed. In addition, it allows greater potential for the initial development of the crop, through defense conditions that are conferred to the plant through the use of pesticides (CASTRO et al., 2008).

The effect of seed treatment is selective and requires less amount of active ingredient when 
compared to other forms of control applications, Fessel et al. (2003) observed that the application of consequently the cost of control is lower (EMBRAPA, 2007). Moreover, it represents only 0.5 to $1.0 \%$ of the production costs of the crops and is considered cheap, therefore, this technology must be increasingly improved and used in other crops, due to its advantages and importance (MENTEN; MORAES, 2010).

The use of industrial seed treatment (TIS) has shown an increase in its adhesion because it is a technology that uses techniques and equipment with precision of dosage. TIS combines the application of insecticides, fungicides, nematicides, micronutrients, among other products (HENNING, 2014). It has many advantages over conventional treatment, such as reducing the risk of intoxication, guaranteeing the use of quality products, carrying out the treatment a short time before the delivery of the product in most cases, promoting better seed coverage and applying the correct dose (FRANÇA-NETO et al., 2015).

Seed submission to the combination of several products can cause phytotoxicity, which affects the physiological quality of the seeds, such as reduction of germination, atrophy of the root system and delay in the development of the aerial part of the plants, directly reflecting the productivity of the crop (HENNING, 2014). combined products with increasing dosages had a negative effect on the germination of corn seeds and this effect was intensified with prolongation of the storage period after treatment.

Dan et al. (2010) highlight the adoption of seed treatment by some seed-producing companies prior to bagging or at the time of seed delivery to the producer. These same authors also warn of the need for more information about the interaction that the pesticides used in the treatment can cause in seed quality.

To check the effects of the combination of seed treatment products, the substrate used in the tests may also influence the results. According to Popinigis (1985), the substrate must have characteristics that meet the needs of the material used, such as aeration, water retention capacity, and free of microorganisms. The types of substrates described for the germination test are blotting paper, paper towel, filter paper and sand, where the choice must be made according to the seed requirement (BRASIL, 2009).

Thus, it is very relevant to carry out research that verifies the effects of the product combination on the physiological quality of the seeds submitted to the industrial treatment after 


\begin{abstract}
storage, as well as the effect of the type of substrate MATERIAL AND METHODS
to be used in the germination tests. Therefore, it

The experiment was conducted at the was aimed to determine the vigor of corn seeds and

Laboratory of Seed Analysis (LAS) of the company the percentage of germination in substrates when submitted to two types of industrial treatment as a Limagrain Brasil SA located in the municipality of Goianésia-GO, with coordinates $49^{\circ} 04^{\prime} 59.6$ "W, function of storage time.

$15^{\circ} 18^{\prime} 04.5^{\prime \prime} \mathrm{S}$, and altitude of 630 meters. The conventional hybrid maize seeds produced in the 2015/2016 crop were subjected to seed treatment with the products described in Table 1.
\end{abstract}

Table 1. Products used to treat conventional hybrid corn seeds Limagrain.

\begin{tabular}{lccc}
\hline Commercial product (CP) & Active ingredient (AI) & Class & $\begin{array}{c}\text { Dose (ml c. p.) for } \\
100 \mathrm{~kg} \mathrm{seeds}\end{array}$ \\
\hline K-Obiol 25 CE & Deltametrina 2,5\% & Insecticide & 4 a 8 \\
Actellic 500 CE & Pirimifós-Metílico 50\% & Insecticide & 0,8 a 1,6 \\
Maxim Advanced & $\begin{array}{c}\text { Metalaxil-M 2\% + Tiabendazol 15\%+ } \\
\text { Fludioxonil 2,5\% }\end{array}$ & Fungicide & 100 a 150 \\
Cruiser 350 FS & Thiametoxan 35\% & Insecticideda & 400 a 600 \\
\hline
\end{tabular}

Conventional hybrid corn seeds Limagrain were treated with two industrial treatments: IST3 (combination of three products - K-Obiol $25 \mathrm{CE}$, Actellic 500 CE, Maxim Advanced) e IST4 (combination of four products - K-Obiol $25 \mathrm{CE}$, Actellic 500 CE, Maxim Advanced, Cruiser 350 FS). For each treatment, $4 \mathrm{~kg}$ of seeds were used.

For the treatments of the seeds, the quantities of all the products were diluted in water, forming a homogeneous syrup. The treatment was done manually by mixing the seeds with the syrup in $2 \mathrm{~kg}$ plastic bags. Soon after, the whole was agitated vigorously and after being passed in the GAMET seed homogenizer with the objective of providing uniform coating of the seeds. Then the seeds were packed in paper bags and stored in a room in the seed laboratory under uncontrolled conditions $\left(17^{\circ} \mathrm{C} \pm 3\right.$ e $\left.\downarrow 75 \% \mathrm{RU}\right)$. Maize seeds were evaluated at 0 and 28 days after treatment.

The effects of the chemical treatments of the seeds on the physiological quality were evaluated by the following tests:

Germination tests with and without vermiculite - Germination tests with and without 
vermiculite - germination tests were carried out using the standard germination test (SGT), according to the recommendations contained in the Rules for Seed Analysis (BRASIL, 2009) and the vermiculite test. For the two tests six replicates of 100 seeds were used in germitest paper moistened with water in the ratio 2.5 times the dry paper weight. In the vermiculite test, this was spread on the paper (approximately $19 \mathrm{~g}$ ). The rolls were then packed in germinators at a temperature of approximately $25^{\circ} \mathrm{C} \pm 2{ }^{\circ} \mathrm{C}$. The evaluations were carried out according to the recommendations contained in the Rules for Seed Analysis (BRASIL, 2009). Normal seedling counts were performed on the seventh day after test placement and the results were expressed as percentage of normal seedlings.

Vigor tests - For the vigor tests were used the accelerated aging, and the test of cold without soil, following the recommendations of Barros et al. (1999). Six replicates of 100 seeds were used for each treatment. In the accelerated aging test, individual gerbils with a wire screen were used, with $40 \mathrm{ml}$ of water being added to the bottom of each gerbox, the seeds were distributed on the canvas in order to cover the surface of the gerbox. The mini-chambers were capped and kept in a
BOD-type incubator at a temperature of $41^{\circ} \mathrm{C}$ for 96 hours. After incubation the seeds were submitted to standard germination test. In the cold test the rolls were conducted in capped plastic boxes and taken to a cold chamber at a temperature of about $10^{\circ} \mathrm{C} \pm 1{ }^{\circ} \mathrm{C}$ where they remained for a period of seven days. After these periods, the rolls were taken to a germinator at a temperature of approximately $25^{\circ} \mathrm{C} \pm 2{ }^{\circ} \mathrm{C}$. The evaluations were carried out in accordance with the recommendations contained in the Rules for Seed Analysis (BRASIL, 2009). The normal seedling count was performed on the fifth day after test placement and the results expressed as percentage of normal seedlings.

\section{Emergency Testing - For emergency} evaluation, emergency tests were carried out in a bed and in autoclaved sand, using three replicates of 200 seeds. The field emergency test was conducted on soil classified as red latosol, with 50 seeds per line of approximately $1.0 \mathrm{~m}$ long and 0.04 $\mathrm{m}$ deep. For the sand emergency test, the sterilization of the sand was performed in a vertical autoclave at $120^{\circ} \mathrm{C}$ for 60 minutes according to Brazil (2009), where the seeds were seeded in plastic trays at a depth of $0.03 \mathrm{~m}$. Evaluations were performed at nine days, and the results, expressed 
as percentage of normal seedlings (NAKAGAWA,

1999).

The experiments were arranged in a completely randomized design (DIC) in a $2 \times 2 \times 2$ factorial scheme (two treatments, two times and two substrates) for the germination test; $2 \times 2 \times 2$ (two treatments, two times and two vigor test) for the vigor test and $2 \times 2 \times 2$ (two treatments, two times and two emergency test) for the emergency test. The statistical assistance program ASSISTAT was used for statistical analysis. The data were submitted to analysis of variance by the F test and when necessary, the Tukey test was applied.

\section{RESULTS AND DISCUSSION}

\section{Germination on paper with and without}

\section{vermiculite}

In the experiment where germination was tested on paper with and without vermiculite, no differences were detected between ITS3 and ITS4. However, it was verified that vermiculite was responsible for a better percentage of germination in maize seeds $(\mathrm{p}<0.05)$ (Table 2), possibly because it presents properties necessary for germination, such as porosity, allowing the movement of water and Air, which favors germination (ALVES et al., 2008).

Table 1. Germination, number of abnormal seedlings and dead seeds of corn with industrial treatment (ITS), on paper with and without vermiculite.

\begin{tabular}{|c|c|c|c|}
\hline \multirow{2}{*}{ Substrate } & Germination & Normal seedlings & Dead seeds \\
\hline & \multicolumn{3}{|c|}{ - } \\
\hline Paper with vermiculite & $92.2^{*}$ & $2.8^{\mathrm{ns}}$ & $3.0^{\mathrm{ns}}$ \\
\hline Paper without vermiculite & $94.6^{*}$ & $3.4^{\mathrm{ns}}$ & $4.0^{\mathrm{ns}}$ \\
\hline CV $(\%)$ & 1.4 & 46.6 & 53.9 \\
\hline DMS & 2.6 & 0.85 & 1.1 \\
\hline
\end{tabular}

* Significant at $5 \%$ probability by the test $\mathrm{F}$. ns Non significant.

The function of the substrate is to maintain meet the physiological requirements of the appropriate conditions for the germination and germination of each seed (BRASIL, 2009). development of the seedlings, thus directly The final percentage of germination was influencing the germination (MARTINS et al., higher in the vermiculite (95\%) sowing when 2012). Therefore, the type of substrate used must compared to the germination in paper without 
vermiculite $(92 \%)$. Similar results were obtained by

Alves et al. (2008) who verified that the vermiculite

substrate had an average emergence percentage of

$98 \%$ in mulungu seeds.

Andrade and Pereira (1994), when evaluating the effect of substrate and temperature on germination and vigor of cedar seeds, verified that the substrates had a significant effect on seed germination. These authors also emphasized that the water retention capacity of each substrate together with the own characteristics that regulate the flow of water to the seeds may have influenced the results, since the roll of paper presented less water retention capacity, which resulted in Lower germination averages.

It is believed that the contact of the product present on the surface of the seed with the vermiculite can cause its absorption and consequently, less phytotoxic effect on the seed. Thus, the percentages of germination with vermiculite use may be higher, as verified in this work.

\section{Vigor tests (accelerated aging $\mathrm{x}$ cold test)}

The germination means obtained in the vigor tests did not differ when comparing the results of the accelerated aging and cold test (Table 3). The results of the vigor tests showed that ITS3 provided higher germination percentage averages when compared to TIS4.

Fessel et al. (2003) observed that the combination of five products used to treat maize seeds also reduced vigor and the reduction was more pronounced with the increase in the dose of used products associated with the longer storage period.

Tabela 2. Vigor, number of abnormal seedlings and dead corn seed with industrial treatment (TIS).

\begin{tabular}{lccc}
\hline \multirow{2}{*}{ Treatament } & Vigor & $\begin{array}{c}\text { Normal } \\
\text { seedlings }\end{array}$ & $\begin{array}{c}\text { Dead } \\
\text { seeds }\end{array}$ \\
\cline { 2 - 4 } TIS3 & $------------------(\%)------------------$ \\
\hline \multirow{2}{*}{ TIS4 } & $93,0^{* *}$ & $3,3^{* *}$ & $3,7^{*}$ \\
\hline CV $(\%)$ & $89,2^{* *}$ & $5,7^{* *}$ & $5,2^{*}$ \\
DMS & 3,5 & 54,7 & 45,3 \\
\hline
\end{tabular}

* Significant at $5 \%$ probability by the test $\mathrm{F}$. ** Significant at $1 \%$ probability by the test $\mathrm{F}$

TIS3: Combination of three products e TIS4: Combination of four products

The number of abnormal seedlings and dead seeds were also higher when more seeds were used in the treatment of seeds (Table 3). These results evidenced the negative effect on the 
physiological quality of the seeds when more products are used in the seed treatment.

In the TIS4 treatment the added product was thiametoxan (Table 1). Castro et al. (2008) verified in soybean seeds treated with this product lower values of germination and greater number of abnormal and dead plants than the control. These authors concluded that thiametoxan was harmful to the development of the seedlings, providing physiological changes and interfering in the initial development of the plants. However, Borges et al. (2016) verified that thiametoxan promoted a higher percentage of normal seedlings in peanut seeds presenting positive responses in the germination and vigor test when compared to the control.

Although there was no difference between the vigor tests, significant interaction of the tests with time was observed (Table 4). In the accelerated aging test, the percentage of germination as a function of time was observed. In addition, seeds submitted to the cold test presented greater vigor when compared to the accelerated aging test 28 days after treatment.

Tabela 3. Vigor corn seed (\%) obtained in tests of accelerated aging and cold test stored after treatment of the seed.

\begin{tabular}{|c|c|c|}
\hline \multirow{2}{*}{ Days after storage } & Accelerated aging test & Cold test \\
\hline & \multicolumn{2}{|c|}{ (10 } \\
\hline 0 & $92.5 \mathrm{Aa}$ & $90.7 \mathrm{Aa}$ \\
\hline 28 & $88.5 \mathrm{Bb}$ & $92.8 \mathrm{Aa}$ \\
\hline
\end{tabular}

\begin{tabular}{ll}
\hline CV $(\%)$ & 3.5 \\
DMS & 1.9
\end{tabular}

Means followed by the same lowercase letter in the column and upper case in the row do not differ by Tukey test at the $5 \%$ probability level.

According to Marcos Filho (1999), the submitted to the accelerated aging chamber accelerated aging test subjects the seed to humidity (GARCIA; NOGUEIRA; ABREU, 2004). Also and high temperatures, where its rate of according to these authors, temperature of $40^{\circ} \mathrm{C}$ deterioration increases considerably through its for $96 \mathrm{~h}$, provided reduced seed vigor resulting in exposure to these factors. Another agent that leads delayed germination in Angico-Branco to the degeneration of seed and that affects its (Anadenanthera colubrina). Santos et al. (2002), germinative power is the incidence of fungi when also observed a decreasing value in the results 


\begin{abstract}
obtained in the germination test as the time of of normal seedlings in the accelerated aging test, exposure to the accelerated aging increased, and and, from the increase in dose, the percentages they concluded that with the use of the began to decrease. Dan et al. (2010) observed a temperature of $42^{\circ} \mathrm{C}$, the exposure time of 72 reduction in the vigor of soybean seeds with the hours was presented more efficient in increase of the storage period, however, the seeds differentiating lots at levels of vigor.

treated with thiametoxan presented vigor levels

Borges et al. (2014) observed that rice seeds above $80 \%$ when submitted to storage for 45 days treated with thiametoxam showed higher in the soybean crop. According to Borges et al. germination when compared to untreated seeds, (2016) doses of thiametoxan up to $200 \mathrm{ml} 100 \mathrm{~kg}$ yet according to the same authors the prolongation 1 stimulates the physiological development of of the storage period was responsible for the peanut seeds.
\end{abstract}

reduction of germination independent of the dose used.

\title{
Emergency soil and sand
}

In the soil and sand emergency

Lauxen, Villela and Soares (2010), when evaluating the physiological performance of cottonseed treated with thiametoxan, concluded that the use of doses 4,$5 ; 4.9$ and $5.3 \mathrm{~mL}$ of Cruiser ${ }^{\circledR} 350$ FS kg-1 of seed showed satisfactory experiments, the TIS3 and TIS4 treatments on corn seeds showed a germination percentage of 95.7 and 93.6, respectively, with $\mathrm{p}>0.01$ (Table 5). The highest germination value was observed when a smaller number of combined products were used. variation, corresponding to the highest percentages

Tabela 4. Emergence of maize seedlings submitted to industrial treatment (TIS).

\begin{tabular}{lcc} 
& Treataments & Emergence $(\%)$ \\
\hline TIS3 & $95,7^{* *}$ \\
TIS4 & $93,6^{* *}$ \\
\hline CV (\%) & 1,6 \\
DMS & 1,3 \\
\hline
\end{tabular}

** Significativo a $1 \%$ de probabilidade pelo teste $\mathrm{F}$

TIS3: Combinação de três produtos e TIS4: Combinação de quatro produtos. 


\section{CONCLUSION}

The addition of vermiculite in the paper germination test favors the germination of industrially treated corn seeds.

When added thiametoxan the combination of products in the treatment of corn seeds found detrimental effect to their physiological quality providing reduction in germination and vigor.

The industrially treated corn seeds showed a reduction in vigor when submitted to the aging test after the prolongation of the storage period.

\section{ACKNOWLEDGMENTS}

To God for all that I have conquered and for the realization of this dream

My advisor Joseanny Cardoso da Silva Pereira, for his dedication, understanding, availability, beyond patience and teaching.

To my colleagues in the seed analysis laboratory, for giving space for the experiments, especially to João Ortolan, an example of person and professional with whom I had the privilege of living and learning with their immense knowledge.

Limagrain, for giving space and material for the realization of the experiments.

\section{REFERENCES}

AGUILERA LA, CARON BO, CELLA WL \& LERSCH JUNIOR I (2000) Qualidade fisiológica de sementes de milho em função da forma e do tratamento químico das sementes. Ciência Rural, Santa Maria, v. 30, n. 2, p. 211-215.

ALVES EU, ANDRADE LA, BARROS HHA, GONÇALVES EP, ALVES AU, GONCALVES GS, OLIVEIRA LSB \& CARDOSO EA (2008) Substratos para testes de emergência de plântulas e vigor de sementes de Erythrina velutina Willd., Fabaceae. Semina Ciências Agrárias, Londrina, v. 29, n. 1, p. 69-82.

ANDRADE ACS \& PEREIRA, TS (1994) Efeito do substrato e da temperatura na germinação e no vigor de sementes de cedro - Cedrela odorata L. (MELIACEAE). Revista Brasileira de Sementes, Londrina, v. 16, n. 1, p. 34-40.

BARROS ASR, DIAS MCLL, CICERO SM \& KRZYZANOWSKI FCR (1999) Teste de frio. In: KRZYZANOWSKI FC, VIEIRA RD \& FRANÇA NETO JB (Ed.). Vigor de semente: conceitos e testes, Londrina: ABRATES. Cap. 5, p. 1-15.

BRASIL. Ministério da Agricultura, Pecuária e Abastecimento. Regras para análise de sementes. Brasília: SNDA/DNDV/CLAV, 2009. 399 p.

BORGES CT, ALMEIDA AS, JAUER A, TUNES LM \& MENEGHELLO GE (2014) Efeito do tiametoxam na qualidade fisiológica de sementes de arroz submetido a armazenamento. Revista Enciclopédia Biosfera, Goiânia, v. 10, n. 19; p. 882.

BORGES CT, ALMEIDA AS, DEUNER C, TROYJACK C, JAUER A \& MENEGHELLO GE (2016) Efeito do tiametoxam sobre a qualidade fisiológica de sementes de amendoim. Revista Tecnologia \& Ciência Agropecuária, João Pessoa, v. 10. n. 4, p. 44-48.

CASTRO GSA, BOGIANI JC, SILVA MG, GAZOLA E \& ROSOLEM CA (2008) Tratamento de sementes de soja com inseticidas e um bioestimulante. Pesquisa Agropecuária Brasileira, Brasília, v. 43, n. 10, p. 1311-1318. 
DAN LGM, DAN HA, BARROSO ALL \& BRACCINI AL (2010) Qualidade fisiológica de sementes de soja tratadas com inseticidas sob efeito do armazenamento. Revista Brasileira de Sementes, Londrina, v. 32, n. 2, p. 131-139.

DHINGRA OD (1985) Importância e perspectivas do tratamento de sementes no Brasil. Revista Brasileira de Sementes, Brasília, ano 7, n. 1, p. 133-138.

\section{EMPRESA BRASILEIRA DE PESQUISA E} AGROPECUÁRIA

(EMBRAPA).

Tratamento de sementes no controle das pragas iniciais do milho. 2007. Disponível em: $<$ http://www.cnpms.embrapa.br/publi cacoes/publica/pragas iniciais do milho.p df>. Acesso em: 17 mar. 2016.

FRANÇA NETO JB, HENNING AA, KRZYZANOWSKI FC, HENNING FA \& LORINI I (2015) Adoção do tratamento industrial de sementes de soja no Brasil, safra 2014/15. Londrina: Informativo ABRATES, v. 25, n. 1.

FESSEL SA, MENDONÇA EAF, CARVALHO RV \& VIEIRA RD (2003) Efeito do tratamento químico sobre a conservação de sementes de milho durante $\mathrm{O}$ armazenamento. Revista Brasileira de Sementes, Londrina, v. 25, n. 1, p. 25-28.

FUCK MPF \& BONACELLI MB (2007) A pesquisa pública e a indústria sementeira nos segmentos de sementes de soja e milho híbrido no Brasil. Revista Brasileira de Inovação, Rio de Janeiro, v. 6, n. 1, p. 87121.

GARCIA LC, NOGUEIRA AC \& ABREU DCA (2004) Influência do envelhecimento acelerado no vigor de sementes de Anadenanthera colubrina (vellozo) Brenan Mimosaceae. Ciência Florestal, Santa Maria, v. 14, n. 1, p. 85-90.

GOULART ACP (1993) Tratamento de sementes de milho (Zea mays L.) com fungicidas. Revista Brasileira de Sementes, Londrina, v. 15, n. 2, p. 165-169.
GOULART, A.C.P. Fungos em semente de soja: Detecção e Importância. Dourados: Embrapa-CPAO, 1997. 58 p. (Documentos, 11).

HENNING FA, JACOB JUNIOR EA, MERTZ LM \& PESKE ST (2011) Qualidade sanitária de sementes de milho em diferentes estádios de maturação. Revista Brasileira de Sementes, Londrina, v. 33, n. 2, p. 316-321.

HENNING, A. A. Tratamento industrial de sementes ganha espaço. Informação Meridional, Londrina, n. 51, 2014. Disponível em:<http://fundacaomeridional.com.br/artigos /2014/10/08/tratamento-industrial-desementes-ganha-espaco $>$. Acesso em: 10 jun. 2016.

LAUXEN LR, VILLELA FA \& SOARES RC (2010) Desempenho fisiológico de sementes de algodoeiro tratadas com tiametoxam. Revista Brasileira de Sementes, Londrina, v. 32, n. 3, p. 61-68.

MARCOS FILHO J (1999) Teste de envelhecimento acelerado. In: KRZYZANOWSKI FC, VIEIRA RD \& FRANÇA NETO JB (Ed.). Vigor de semente: conceitos e testes. Londrina: ABRATES, cap. 3, p. 1-24.

MARTINS CC, MACHADO CG, SANTANA DG \& ZUCARELI C (2012) Vermiculita como substrato para o teste de germinação de sementes de ipê-amarelo. Semina Ciências Agrárias, Londrina, v. 33, n. 2, p. 533-540.

MENTEN, J. O, MORAES, M. H. D. Tratamento de sementes: histórico, tipos, características e benefício. Londrina: Informativo ABRATES, v. 20, n. 3, p. 52-53, 2010.

NAKAGAWA J (1999) Testes de vigor baseados no desempenho das plântulas. In: KRZYZANOWSKI FC, VIEIRA RD, FRANÇA NETO JB (Ed.). Vigor de sementes: conceitos e testes, Londrina: ABRATES, cap. 2, p. 1-24.

OLIVEIRA ACS (2009) Qualidade fisiológica de sementes de milho armazenadas em diferentes embalagens reutilizáveis sob dois 
ambientes. 2009. 72 f. Dissertação (Mestrado em Produção Vegetal) - Centro de Ciências e Tecnologias Agropecuárias, Universidade Estadual do Norte Fluminense, Campos dos Goytacazes. 2009.

POPINIGIS (1985) Fisiologia da semente. $2^{a}$ ed. Brasília. 289 p.

SANTOS PM, GONDIM TCO, ARAUJO EF \& DIAS DCFS (2002) Avaliação da qualidade fisiológica de sementes de milho-doce pelo teste de envelhecimento acelerado. Revista Brasileira de Sementes, Londrina, v. 24, n. 1, p. 91-96.

SILVA, F. A. S. E.; AZEVEDO, C. A. V. Principal Components Analysis in the Software Assistat-Statistical Attendance. In: World Congress On Computers In

Agriculture, 7, Reno-NV-USA: American Society of Agricultural and Biological

Engineers, 2009. 